UDC 615.9:665.59

\title{
TOXICOLOGICAL CHARACTERISTICS OF PETROLEUM PRODUCTS REPEATED EXPOSURE
}

\author{
V.M. Rubin, I.I. II'yukova \\ RUE "Scientific practical centre of hygiene", Minsk, the Republic of Belarus, \\ the Republic of Belarus, M insk, 8, Academicheskaya St., 220012
}

Abstract. The ability of petroleum products to initiate cumulative effects was assessed in experimental intragastric admission to male albino rats for one month. The analysis of skin-resorptive effects was performed using "test-tube" method on the skin of rats' tails. It has been established that petroleum products can penetrate the intact skin and, with repeated admission, cause a general toxic effect. There were reductions bodyweights, the negative effect on the function of the kidneys and liver, changes of hematological parameters, as well as activation of the antioksidatnoy system. Repeated intragastric administration does not lead to the death of the animals testifying to the lack of accumulation capacity for petroleum products at the level of functional mortal effects, the cumulation coefficient being $>5.1$. Negative impact on urinary function and hepatobiliary system, changes in hematological parameters and activation of the «lipid peroxidation - antioksidant defense» were observed.

Key words: petroleum products, subacute toxicity, skin-resorptive effect.

As a result of human economic activity the soil cover is contaminated with different chemical substances. Currently, the petroleum products are one of the common contaminants of the human living environment. Coming into soil, they can have the negative impact on the health of people due to the direct contact with soil or, indirectly, with water, atmospheric air and plant foods $[5,6]$.

The purpose of work is to study the peculiarities of the toxic impact of petroleum products at the peroral and transdermal routes of intake.

Materials and methods. During the contamination of soil with exogenic chemical substances it is important to assess the ability of substance to penetrate through the unaffected skin and cause the intoxication because this route of intake to human body is prevailing at the contact with soil. The assessment of petroleum products ability to the cutaneous and resorptive action was carried out using the "tet tube" method on the white male rats with weight of 230-280 g. Each control and experimental group consisted of 7 animals. The tails of rats in the experimental group by $2 / 3$ of their length were submerged to the test tube with petroleum products in natural form, the tails of rats in the control group - into water. The exposure time was 4 hours a day, 5 days a week during 30 days. Daily we fixed the exernal signs of irritation and measured the volume of tail (skin puffiness test) immediately after exposure. Weekly all the animals were weighed [4]. The ability of petroleum products to accumulate in the body and affect negatively at the level of fatal effects or affect the functional condition of a number of organs and systems of experimental animals was assessed at the intragastric intake by the white male rats with weight of $200-240 \mathrm{~g}$ in the doses of $1 / 10(3762 \mathrm{mg} / \mathrm{kg})$ and $1 / 20(1881 \mathrm{mg} / \mathrm{kg})$ from the maximum introduced dose in the acute experiment $(37620 \mathrm{mg} / \mathrm{kg})$. The animals of control group received water in the equivalent volume. Each control and experimental group consisted of 7 animals. The duration of experiment was 30 days. The mode of introduction: 5 times a week. Weekly the animals were weighed and the dose was clarified [1, 2, 4]. At the end of experiment the animals were killed through immediate decapitation, and we calculated the relatve weight coefficients for organs (hereinafter referred to as RWC), studied the morphological composition of peripheral blood, determined a number of biochemical indicators in the blood serum and urine, calculated the clearance of creatinine and urea, and the percent of reabsorbtion (under creatinine). The works with animals were performed according to the technical code of established practice TKP 125-2008 902040

(C) Rubin V.M., Il'yukova I.I., 2015

Rubin Viktoria Mikhailovna - post-graduate student (e-mail: V.M.Rubin@ mail.ru; tel. +375 2970260 85).

Ilyukova Irina Ivanovna - candidate of medical science; head of preventive and environmental toxicology laboratory 56 (e-mail: toxlab@ mail.ru; tel. +7 (017) 292-60-27). 
[3].

To carry out the experimental studies we took the mixture of petroleum products in relation 1:1:1 by weight: illuminating oil $\mathrm{KO}-20$ under $\mathrm{TU}$ 38.401-58-10-01 (manufactured by Naftan OJSC), diesel motor fuel EN 590 under TU 38.401-58296-2005 (manufactured by Mozyr Refinery OJSC), and industrial oil I-50A (manufactured by Naftan OJSC).

The results of studies were statistically processed. The median and interquartile range (Me [25\%; 75\%]) was calculated as the characteristics of group for signs with distribution differing from normal. To compare two independent samplings we used the non-parametric $U$-criterion of MannWhitney, and the differences were considered as credible, taking into account Bonferroni correction. $p<0.05$ was taken as the level of significance.

Results and their discussion. Repeated intragastric intake of petroleum products in the doses of 3762 and $1881 \mathrm{mg} / \mathrm{kg}$ did not result in the manifestation of external intoxication sympthoms and death of animals. During the experiment the body weight of experimental animals was within the control indicators. When exposed to petroleum products in the doses of 3762 and $1881 \mathrm{mg} / \mathrm{kg}$ we observed the statistically significant increase in the relative weight coefficients of liver by $21.88 \%$ and kidney by $16.39 \%$ and $13.11 \%$. RWC of heart, lien, adrenal glands and stomach of the experimental animals did not differ from the indicators of animals in the control group (table 1).

During the experiment we observed the impact of the maximum introduced dose of petroleum products on hematological indicators. We registered the increase in the level of hemoglobin (by $12.00 \%$ ), hematocrit (by 8.78\%), thrombocytes (by $27.29 \%$ ) and average thrombocytes volume (by $8.54 \%$ ) (table 2).

One of the reasons for increase in the level of hematocrit can be the decrease of the liquid blood volume because the content of erythrocytes is at the level of control indicator, insignificantly - as a result of increase in the number of thrombocytes. Change of such indicator as the average thrombocyte volume evidences the increase in the number of functionally active thrombocytes in peripheral blood and strengthening of their adhesive and aggregative ability. It is known that there is the relationship of the size of thrombocytes with their functional activity. As a result of activation the discoid form of thrombocytes is replaced by spherical, and the pseudopodia appear that results in the increase of the cell dimensions and degree of anisocytosis. Therefore, the thrombocytes formation induction occurs in the experimental animals when they are exposed to petroleum products.

Table 1

Body weight of rats and RWC of internal organs after the end of 20 -fold intragastric introduction of petroleum products, $\mathrm{Me}[25 \% ; 75 \%]$

\begin{tabular}{|c|c|c|c|}
\hline \multirow[b]{2}{*}{ Indicator } & \multicolumn{3}{|c|}{ Group of animals and dose of introduced petroleum products } \\
\hline & $\begin{array}{c}\text { control, } \\
n=7\end{array}$ & $\begin{array}{l}\text { experimental group } 1 \\
(3762 \mathrm{mg} / \mathrm{kg}), n=7\end{array}$ & $\begin{array}{c}\text { experimental group } 2 \\
(1881 \mathrm{mg} / \mathrm{kg}), n=7\end{array}$ \\
\hline Body weight, $\mathrm{g}$ & $270,0[260,0 ; 290,0]$ & $270,0[260,0 ; 290,0]$ & $250,0[240,0 ; 290,0]$ \\
\hline \multicolumn{4}{|c|}{ Relative weight coefficients (RWC), $\mathrm{kg}^{-3} / \mathrm{kg}$} \\
\hline - liver & $26,50[24,90 ; 9,30]$ & $32,30[30,40 ; 2,80]^{*}$ & $32,30[29,70 ; 3,30]^{*}$ \\
\hline - kidney & $6,10[5,70 ; 6,50]$ & $7,10[6,50 ; 7,30]^{*}$ & $6,90[6,50 ; 7,70]^{*}$ \\
\hline - heart & $3,30[3,10 ; 3,60]$ & $3,40[3,40 ; 3,70]$ & $3,60[3,20 ; 3,80]$ \\
\hline- lien & $3,80[3,50 ; 5,10]$ & $3,50[3,30 ; 5,10]$ & $4,60[4,10 ; 5,30]$ \\
\hline - adrenal glands & $0,17[0,15 ; 0,18]$ & $0,16[0,14 ; 0,18]$ & $0,17[0,15 ; 0,20]$ \\
\hline - stomach & $6,20[5,20 ; 6,70]$ & $6,30[5,80 ; 7,30]$ & $6,70[6,40 ; 7,04]$ \\
\hline
\end{tabular}

Note: $*$ - the differences are statistically significant in relation to control, $p<0.05$. 
Hematological indicators of the peripheral blood of rats after the end of 20-fold intragastric introduction of petroleum products, $\mathrm{Me}[25 \% ; 75 \%]$

\begin{tabular}{|l|c|c|c|}
\hline \multirow{2}{*}{\multicolumn{1}{|c|}{ Indicator }} & \multicolumn{3}{|c|}{ Group of animals and dose of introduced petroleum products } \\
\cline { 2 - 4 } & $\begin{array}{c}\text { control, } \\
n=7\end{array}$ & $\begin{array}{c}\text { experimental group 1 } \\
(3762 \mathrm{mg} / \mathrm{kg}), n=7\end{array}$ & $\begin{array}{c}\text { experimental group } 2 \\
(1881 \mathrm{mg} / \mathrm{kg}), n=7\end{array}$ \\
\hline Erythrocytes, $10^{12} / 1$ & $7,54[7,10 ; 7,80]$ & $7,92[7,79 ; 8,19]$ & $7,36[7,04 ; 8,14]$ \\
\hline Hematocrit, $\%$ & $55,80[53,50 ; 57,10]$ & $60,70 *[58,20 ; 61,6]$ & $58,30[54,10 ; 63,60]$ \\
\hline Hemoglobin, g/l & $126,0[124,0 ; 130,0]$ & $140,0 *[137,0 ; 146,0]$ & $133,0[125,0 ; 143,0]$ \\
\hline Thrombocytes, $10^{9} / 1$ & $372,0[324,0 ; 405,0]$ & $476,0 *[422,0 ; 483,0]$ & $379,0[347,0 ; 418,0]$ \\
\hline Average erythrocyte volume, fl & $75,70[72,80 ; 77,70]$ & $75,00[74,20 ; 76,80]$ & $78,10[74,50 ; 79,20]$ \\
\hline Average thrombocyte volume, fl & $8,20[8,00 ; 8,60]$ & $8,90 *[8,70 ; 9,10]$ & $8,40[8,10 ; 8,60]$ \\
\hline $\begin{array}{l}\text { Average content of hemoglobin in } \\
\text { erythrocyte, pg }\end{array}$ & $17,20[16,20 ; 17,90]$ & $17,70[16,80 ; 18,10]$ & $16,70[16,30-19,40]$ \\
\hline $\begin{array}{l}\text { Average concentration of hemog- } \\
\text { lobin in erythrocyte, g/l }\end{array}$ & $230,0[222,0 ; 237,0]$ & $235,0[226,0 ; 241,0]$ & $222,0[206,0 ; 246,0]$ \\
\hline Leukocytes, $10^{9} / 1$ & $13,10[12,20 ; 18,10]$ & $14,80[11,60 ; 22,10]$ & $18,90[15,30 ; 19,70]$ \\
\hline
\end{tabular}

Note: * the differences are statistically significant in relation to control, $p<0.05$.

Table 3

Indicators of the urinary system of rats after the end of 20-fold intragastric introduction of petroleum products, $M e[25 \% ; 75 \%]$

\begin{tabular}{|c|c|c|c|}
\hline \multirow[b]{2}{*}{ Indicator } & \multicolumn{3}{|c|}{ Group of animals and dose of introduced petroleum products } \\
\hline & $\begin{array}{l}\text { control, } \\
n=7\end{array}$ & 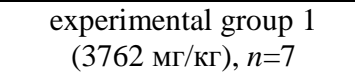 & $\begin{array}{c}\text { experimental group } 2 \\
(1881 \text { мг/кг), } n=7\end{array}$ \\
\hline Daily urine, $\mathrm{ml} / \mathrm{day}$ & $6,50[5,20 ; 8,00]$ & $11,70[3,60 ; 13,30]$ & $5,40[2,00 ; 9,60]$ \\
\hline $\mathrm{pH}$ & $5,00[5,00 ; 5,50]$ & $6,50[6,00 ; 7,00]^{* *}$ & $5,40[2,00 ; 9,60]$ \\
\hline Specific weight, $\mathrm{g} / \mathrm{cm}^{3}$ & $0,97[0,93 ; 0,99]$ & $1,00[0,94 ; 1,01]$ & $0,97[0,94 ; 1,007]$ \\
\hline Total protein, $\mathrm{g} / \mathrm{l}$ & $5,40[4,50-8,50]$ & $3,70[3,10 ; 4,40]^{*}$ & $5,90[4,20 ; 8,50]$ \\
\hline Chlorides, $\mathrm{mM} / \mathrm{l}$ & $47,61[35,71 ; 66,66]$ & $90,47[71,42 ; 109,52]^{*}$ & $114,28[100,0 ; 128,57]^{* *}$ \\
\hline Urea, mM/l & $280,5[242,5 ; 402,0]$ & $140,5[127,50 ; 153,0]^{* *}$ & $395,5[351,0 ; 957,0]$ \\
\hline Creatinine, mcM/l & $4580,0[4270,0 ; 5800,0]$ & $2725,0[2725,0 ; 3050,0] * *$ & $5495,0[4580,0 ; 12510,0]$ \\
\hline Urea clearance, $\mathrm{ml} / \mathrm{min}$ & $0,13[0,10 ; 0,32]$ & $0,12[0,09 ; 0,20]$ & $0,20[0,18 ; 0,26]$ \\
\hline Creatinine clearance, $\mathrm{ml} / \mathrm{min}$ & $0,34[0,27 ; 0,52]$ & $0,41[0,10 ; 0,45]$ & $0,37[0,27 ; 0,49]$ \\
\hline $\begin{array}{l}\text { Percent of reabsorbtion (under } \\
\text { creatinine) }\end{array}$ & $98,67[98,53 ; 98,95]$ & $97,76[97,54 ; 98,18]$ & $98,99[98,46 ; 99,46]$ \\
\hline
\end{tabular}

Note: $*$ - the differences are statistically significant in relation to control, $p<0.05$; $* *$ - the differences are statistically significant in relation to control, $p<0.01$.

During the introduction of petroleum products in the dose of $3762 \mathrm{mg} / \mathrm{kg}$ the animals had the statistically significant changes of some functional indicators of urinary system (table 3 ).

In urine we detected the decrease in the content of total protein by $31.48 \%$, urea - by $49.9 \%$ and creatinine - by $40.50 \%$, herewith their blood serum level was within control (table 4). The changes mentioned above occurred at the background of increase in diuresis by $80 \%$, however the differences were not statistically significant. The clearance of creatinine and urea as well as the percent of reabsorbtion in the experimental animals did not differ from control.

During the introduction of petroleum products in the lower dose $(1881 \mathrm{mg} / \mathrm{kg})$ we detected the trend in relation to the increase of urine content of urea by $41 \%$ and creatinine by $20 \%$, as well as the increase of their clearance by $53 \%$, but these changes were not statistically significant in relation to control. The increase in the excretion of chlorides with urine was observed in two experimental groups, but it was not dosedependent. At the does of petroleum products of $1881 \mathrm{mg} / \mathrm{kg}$ the content of chlorides in urine exceeded the control indicator by 2.4 times, at the dose of $3762 \mathrm{mg} / \mathrm{kg}$ - by $90.02 \%$. The detected changes in the biochemical indicators of urine of experimental animals as well as the increase of kidney RWC can evidence the kidney function disorder at the repeated intragastric impact of petroleum products.

On the background of increase of liver RWC in the animals of two experimental groups the biochemical indicators characterizing the functional condition of hepatobiliary system (activity of enzymes of aspartate aminotransferase and alanine aminotransferase, lactate dehydrogenase, alkaline 
phosphatase and content in the blood serum of total protein, lipids, chlorides, urea and creatinine). The activity of enzymes of lactate dehydrogenase and succinate dehydrogenase in the blood hemolysates also was within control (table 4).

Together with it, we observed the increase in the content of total bilirubin in blood: at dose of $3762 \mathrm{mg} / \mathrm{kg}$ - by $148.5 \%$, at dose of $1881 \mathrm{mg} / \mathrm{kg}-$ by $88.73 \%$. The increased content of hematogenic pigment formed as a result of degradation, on the background of the absence of changes in the level of erythrocytes in blood is associated with the liver function disorder.

The intake of petroleum products during one month at the intragastric introduction resulted in the changes of lipidic exchange. On the background of non-changed content of total lipids we observed the decrease in the level of triglycerides by $53.85 \%$ and $35.16 \%$ - in the $1^{\text {st }}$ and $2^{\text {nd }}$ experimental groups respectively and cholesterol by 2 times - in the $1^{\text {st }}$ experimental group.

Table 4

Biochemical indicators in rats after the end of 20-fold intragastric introduction of petroleum products, $M e$ [25\%; 75\%]

\begin{tabular}{|c|c|c|c|}
\hline \multirow[b]{2}{*}{ Indicator } & \multicolumn{3}{|c|}{ Group of animals and dose of introduced petroleum products } \\
\hline & $\begin{array}{l}\text { control, } \\
n=7\end{array}$ & $\begin{array}{l}\text { experimental group } 1 \\
(3762 \mathrm{mg} / \mathrm{kg}), n=7\end{array}$ & $\begin{array}{l}\text { experimental group } 2 \\
(1881 \mathrm{mg} / \mathrm{kg}), n=7\end{array}$ \\
\hline Total blood serum protein, $\mathrm{g} / \mathrm{l}$ & $62,90[61,3 ; 64,5]$ & $66,20[63,80 ; 69,90]$ & $70,30[64,40 ; 76,10]$ \\
\hline Blood serum urea, $\mathrm{mmol} / \mathrm{l}$ & $8,17[6,76 ; 9,44]$ & $8,79[6,89 ; 9,31]$ & $6,89[6,00 ; 8,42]$ \\
\hline Blood serum chlorides, mmol/l & $123,80[119,04 ; 128,6]$ & $128,57[123,80 ; 138,09]$ & $\begin{array}{c}128,57[123,80 \\
133,33] \\
\end{array}$ \\
\hline Blood serum creatinine, $\mathrm{mcMol} / \mathrm{l}$ & $61,00[54,9 ; 67,1]$ & $61,00[61,00 ; 67,10]$ & $61,00[54,90 ; 67,10]$ \\
\hline Blood serum aspartate aminotransferase, $\mathrm{mccat} / \mathrm{l}$ & $4,59[4,12 ; 6,25]$ & $3,72[3,29 ; 5,24]$ & $4,10[3,29 ; 4,33]$ \\
\hline Blood serum alanine aminotransferase, mccat/l & $0,96[0,87 ; 1,08]$ & $0,84[0,76 ; 0,96]$ & $0,82[0,76 ; 1,05]$ \\
\hline Total blood serum bilirubin, $\mathrm{mcMol} / \mathrm{l}$ & $70,26[60,87 ; 80,43]$ & $\begin{array}{c}174,62 * * *[112,80 \\
206,50]\end{array}$ & $\begin{array}{c}132,60 *[117,30 \\
171,70]\end{array}$ \\
\hline Total blood serum lipids, $\mathrm{g} / \mathrm{l}$ & $5,50[5,00 ; 6,00]$ & $6,00[5,25 ; 6,50]$ & $6,00[5,75 ; 7,00]$ \\
\hline Blood serum triglycerides, $\mathrm{mmol} / \mathrm{l}$ & $0,91[0,72 ; 0,93]$ & $0,42 * *[0,31 ; 0,58]$ & $0,59 *[0,49 ; 0,67]$ \\
\hline Blood serum cholesterol, $\mathrm{mmol} / \mathrm{l}$ & $1,00[0,90 ; 1,30]$ & $0,50 *[0,40 ; 0,70]$ & $1,20[0,90 ; 1,80]$ \\
\hline Blood serum lactate dehydrogenase, mccat/l & $74,83[58,83 ; 96,17]$ & $66,83[50,83 ; 88,17]$ & $58,83[48,17 ; 77,50]$ \\
\hline Blood serum alkaline phosphatase, mccat/l & $6,25[3,9 ; 6,73]$ & $6,57[5,64 ; 7,28]$ & $5,87[4,9 ; 6,97]$ \\
\hline $\begin{array}{l}\text { Lactate dehydrogenase in liver homogenate, } \mathrm{mcM} \\
\text { NADN/g of protein }\end{array}$ & $67,50[59,3 ; 77,5]$ & $73,00[69,20 ; 79,80]$ & $79,50[76,50 ; 93,50]$ \\
\hline $\begin{array}{l}\text { Succinate dehydrogenase in liver homogenate, } \mathrm{mcg} \\
\text { formazan/g of protein }\end{array}$ & $20,60[17,6 ; 28,0]$ & $27,20[25,50 ; 31,20]$ & $25,70[24,00 ; 33,20]$ \\
\hline $\begin{array}{l}\text { Glucose-6-phosphate-dehydrogenase in blood he- } \\
\text { molysates, mcM NADFN/min g Nv }\end{array}$ & $\begin{array}{c}87,90 \\
{[77,8 ; 95,7]} \\
\end{array}$ & $95,20[87,30 ; 98,00]$ & $93,92[78,70 ; 114,80]$ \\
\hline $\begin{array}{l}\text { Glutathione reductase in blood hemolysates, } \\
\mathrm{mcMol} / \mathrm{g} \mathrm{Nv} \text { min. }\end{array}$ & $1,70[1,66 ; 2,50]$ & $2,80 *[2,30 ; 3,70]$ & $2,90 * * *[2,30 ; 3,10]$ \\
\hline $\begin{array}{l}\text { Glutathione transferase in blood hemolysates, } \\
\mathrm{mcMol} / \mathrm{g} \mathrm{Nv} \text { min }\end{array}$ & $1,40[1,30 ; 1,50]$ & $1,30[1,20 ; 1,40]$ & $1,20[1,00 ; 1,50]$ \\
\hline $\begin{array}{l}\text { Superoxide dismutase in blood hemolysates, } \\
\mathrm{mcg} / \mathrm{ml}\end{array}$ & $30,40[26,7 ; 36,3]$ & $47,40 *[36,30 ; 47,40]$ & $36,30[26,70 ; 36,30]$ \\
\hline Free SH-groups in blood hemolysates, $\mathrm{mcM} / \mathrm{ml}$ & $86,10[78,8 ; 90,0]$ & $\begin{array}{c}102,60 * *[100,80 \\
104,40] \\
\end{array}$ & $\begin{array}{c}102,60 *[97,00 \\
106,30] \\
\end{array}$ \\
\hline Blood serum malonic dialdehyde, $\mathrm{nmol} / \mathrm{ml}$ & $5,00[5,00 ; 7,50]$ & $10,00 *[7,50 ; 12,50]$ & $7,50[5,00 ; 10,00]$ \\
\hline Blood serum bitirosine, conventional units & $6,07[5,98 ; 9,23]$ & $5,22[5,01 ; 6,51]$ & $5,12[5,03 ; 6,07]$ \\
\hline Blood serum tryptophan, conventional units & $32,65[27,20 ; 37,85]$ & $38,44[32,26 ; 39,76]$ & $29,59[28,35 ; 33,18]$ \\
\hline
\end{tabular}

Note: $*$ - the differences are statistically significant in relation to control, $p<0.05 ; * *$ - the differences are statistically significant in relation to control, $p<0.01 ; * * *-$ the differences are statistically significant in relation to control, $p<0.1$.

The impact of the components of petroleum products caused the increased formation of free radicals and activation of lipid peroxidation (LP) that is evidenced by the increased final LP product - malonic dialdehyde. At the dose of $3762 \mathrm{mg} / \mathrm{kg}$ we established the statistically significant increased of its content in blood serum by 2 times; at the dose of $1881 \mathrm{mg} / \mathrm{kg}$ - by $25 \%$, though the differences are not statistically significant. In response to the LP product accumulation we observed the activation of multicomponent selfregulating antioxidative system (AOS) of body. According to table 4, the intake of petroleum products at the dose of $3762 \mathrm{mg} / \mathrm{kg}$ was accompanied 
by the increase in the activity of superoxide dismutase enzymes (by 55.9\%) and glutathione reductase (by $64.7 \%$ ). At the dose of $1881 \mathrm{mg} / \mathrm{kg}$ we observed only the increase in the activity of glutathione reductase (by 70.5\%). Herewith, the activity of glucose-6-phosphate-dehydrogenase and glutathione transferase was at the level of control value. The ccontent of SH-groups in blood hemolysates non-fermentative AOS link - as statistically significantly increased in the animals of both experimental groups by $19.2 \%$. The changed in the content of bitirosine and tryptophan in the blood serum of animals of both experimental groups is not observed that eviences the absence of the oxidative modification of proteins. Therefore, the intake of petroleum products to the body of animals during 1 month at the intragastric route of intake resulted in the LPAOS system activiation.

In the conditions of long-term epicutaneous impact on $2 / 3$ of the surface of tails of white rats of the maximum possible quantities of petroleum products not external sympthoms of intoxication as well as the death of animals was observed. At the daily visual assessement of the condition of skin on the tails of rats we did not detected the signs of erythema (the intensity of erythema was 0 points) as well as the development of edema by which we justified the change in the volume of the tails of rats measures before and after exposure.

During the experiment we established the statistically significant decrease of body weight in the rats of experimental group by $11.3 \%$ and increase of liver RWC by $11.2 \%$ that evidences the toxic impact on the body of animals (table 5).

When studying the functional condition of urinary system we established the statistically significcant content of urea in urine by $77.9 \%$. At the same time, the content of urea in the blood serum of the rats of experimental group and urea clearance did not differ from the indicators of animals of parallel control (tables 6, 7). The content of creatinine in the urine of experimental animals was at the level of control values. Together with it, we observed the statistically significant increase in the creatinine concentration in the blood serum by $10 \%$ as well as the decrease of integral indicator in animals - clearance of creatinine by 1.9 times. These changes occurred on the background of daily urine decrease by $42 \%$, but however the changes are not statistically significant. The obtained results can evidence the glomerular filtration disorder of the nitrogen metabolism products by kidney.

When considering the biochemical blood serum indicators characterizing the functional condition of liver we did not observe any changes in the content of total protein, chlorides and activity of enzymes of lactate dehydrogenase, alkaline phosphatase, aspartate aminotransferase and alanine aminotransferase in the animals exposed to petroleum products (table 7).

Table 5

RWC of internal organs and body weight of rats exposed to petroleum products on the skin of $2 / 3$ of tails during one month, $\mathrm{Me}$ [25\%; 75\%]

\begin{tabular}{|l|c|c|}
\hline \multirow{2}{*}{ Indicator } & \multicolumn{2}{|c|}{ Group } \\
\cline { 2 - 3 } & control, $n=7$ & experiment, $n=7$ \\
\hline Body weight, 1 & $270[250 ; 280]$ & $240[220 ; 260]^{*}$ \\
\hline Liver RWC, $\mathrm{kg}^{-3} / \mathrm{kg}$ & $26,50[25,46 ; 27,81]$ & $28,48[28,38 ; 29,36]^{*}$ \\
\hline Kidney RWC, kg $\mathrm{kg}^{-3} / \mathrm{kg}$ & $6,00[5,80 ; 6,93]$ & $6,88[6,67 ; 7,50]$ \\
\hline Heart RWC, $\mathrm{kg}^{-3} / \mathrm{kg}$ & $3,38[3,21 ; 3,92]$ & $3,80[3,45 ; 4,50]$ \\
\hline Lien RWC, $\mathrm{kg}^{-3} / \mathrm{kg}$ & $3,76[3,69 ; 4,39]$ & $4,22[3,35 ; 4,50]$ \\
\hline RWC of adrenal glands, $\mathrm{kg}^{-3} / \mathrm{kg}$ & $1,80[1,43 ; 1,93]$ & $1,67[1,32 ; 1,95]$ \\
\hline
\end{tabular}

Note: * - the differences are statistically significant in relation to control, $p<0.05$. 
Indicators of the urinary system of rats exposed to petroleum products on the skin of $2 / 3$ of tails during one month, $\mathrm{Me}[25 \% ; 75 \%]$

\begin{tabular}{|l|c|c|}
\hline \multirow{2}{*}{ Indicator } & \multicolumn{2}{c|}{ Group } \\
\cline { 2 - 3 } & control, $n=7$ & experiment, $n=7$ \\
\hline Daily urine, ml/day & $15,7[14,0 ; 16,1]$ & $9,10[5,70 ; 14,50]$ \\
\hline $\mathrm{pH}$ & $6,5[6,5 ; 6,5]$ & $6,5[6,5 ; 6,5]$ \\
\hline Specific weight, g/cm ${ }^{3}$ & $0,99[0,98 ; 1,01]$ & $0,99[0,99 ; 1,01]$ \\
\hline Total protein, $\mathrm{g} / \mathrm{l}$ & $1,4[1,0 ; 1,7]$ & $1,3[1,2 ; 1,6]$ \\
\hline Chlorides, $\mathrm{mM} / \mathrm{l}$ & $19,31[13,63 ; 22,72]$ & $13,63[11,36 ; 18,18]$ \\
\hline Urea, $\mathrm{mM} / \mathrm{l}$ & $86,0[76,5 ; 96,0]$ & $153,0[134,0 ; 178,5]^{*}$ \\
\hline Creatinine, $\mathrm{mcM} / \mathrm{l}$ & $3050,0[3050,0 ; 3355,0]$ & $3355,0[2745,0 ; 3355,0]$ \\
\hline Urea clearance, $\mathrm{ml} / \mathrm{min}$ & $0,16[0,11 ; 0,18]$ & $0,16[0,07 ; 0,22]$ \\
\hline Creatinine clearance, ml/min & $0,61[0,51 ; 0,67]$ & $0,31[0,17 ; 0,50]^{*}$ \\
\hline Percent of reabsorbtion (under creatinine) & $98,21[97,80 ; 98,95]$ & $97,82[97,56 ; 98,00]$ \\
\hline
\end{tabular}

Note: $*$ - the differences are statistically significant in relation to control, $p<0.05$.

Table 7

Biochemical indicators of rats exposed to petroleum products on the skin of $2 / 3$ of tails during one month, $M e[25 \% ; 75 \%]$

\begin{tabular}{|l|c|c|}
\hline \multicolumn{2}{|c|}{ Indicator } & \multicolumn{2}{c|}{ Group } \\
\cline { 2 - 3 } & control, $n=7$ & experiment, $n=7$ \\
\hline Total blood serum protein, g/l & $62,7[61,00 ; 70,90]$ & $69,50[68,00 ; 78,50]$ \\
\hline Blood serum urea, mmol/l & $6,89[5,10 ; 9,31]$ & $8,55[7,66 ; 8,68]$ \\
\hline Blood serum chlorides, mmol/l & $131,81[131,81 ; 136,36]$ & $131,81[122,7 ; 136,4]$ \\
\hline Blood serum creatinine, mcMol/l & $61,0[48,8 ; 67,1]$ & $67,1[67,1 ; 73,2]^{* *}$ \\
\hline Blood serum aspartate aminotransferase, mccat/l & $3,84[3,67 ; 4,33]$ & $3,81[3,45 ; 4,65]$ \\
\hline Blood serum alanine aminotransferase, mccat/l & $0,99[0,90 ; 1,08]$ & $0,99[0,79 ; 1,05]$ \\
\hline Total blood serum bilirubin, mcMol/l & $53,7[47,82 ; 76,95]$ & $70,27[64,12 ; 72,4]$ \\
\hline Total blood serum lipids, g/l & $6,18[4,97 ; 6,47]$ & $4,95[4,00 ; 5,28]$ \\
\hline Blood serum triglycerides, mmol/l & $75,3[70,0 ; 77,70]$ & $78,10[71,0 ; 100,40]$ \\
\hline Blood serum cholesterol, mmol/l & $23,10[22,8 ; 26,0]$ & $30,50[27,3 ; 34,2]^{* *}$ \\
\hline Blood serum lactate dehydrogenase, mccat/l & $5,0[4,5 ; 6,0]$ & $6,0[5,25 ; 6,70]$ \\
\hline Blood serum alkaline phosphatase, mccat/l & $0,51[0,46 ; 0,57]$ & $0,55[0,46 ; 0,59]$ \\
\hline Lactate dehydrogenase in liver homogenate, mcM NADN/g of protein & $1,20[1,10 ; 1,30]$ & $1,50[1,10 ; 1,70]$ \\
\hline Succinate dehydrogenase in liver homogenate, mcg formazan/g of protein & $85,20[74,70 ; 96,00]$ & $104,0[91,30 ; 112,0] *$ \\
\hline $\begin{array}{l}\text { Glucose-6-phosphate-dehydrogenase in blood hemolysates, mcM } \\
\text { NADFN/min g Nv }\end{array}$ & $1,7[1,2 ; 1,7]$ & $4,30[3,1 ; 4,8] * *$ \\
\hline Glutathione reductase in blood hemolysates, mcMol/g Nv min. & $1,0[0,80 ; 1,30]$ & $0,90[0,75 ; 1,00]$ \\
\hline Glutathione transferase in blood hemolysates, mcMol/g Nv min & $31,00[25,00 ; 39,00]$ & $28,0[25,0 ; 31,0]$ \\
\hline Superoxide dismutase in blood hemolysates, mcg/ml & $97,10[87,9 ; 102,60]$ & $93,40[84,3 ; 102,6]$ \\
\hline Free SH-groups in blood hemolysates, mcM/ml & $5,0[2,5 ; 6,25]$ & $5,0[2,5 ; 7,50]$ \\
\hline Blood serum malonic dialdehyde, nmol/ml & $0,62[0,49 ; 0,91]$ & $0,67[0,59 ; 0,86]$ \\
\hline Blood serum bitirosine, conventional units & $24,73[22,43 ; 25,84]$ & $23,43[22,32 ; 27,74]$ \\
\hline
\end{tabular}

Note: $*$ - the differences are statistically significant in relation to control, $p<0.05 ; * *-$ the differences are statistically significant in relation to control, $p<0.01$.

The results of study demonstrated that the liver of rats had the activation of marker enzyme of the cycle of tricarboxylic acids - succinate dehydrogenase the activity of which was increased in the experimental animals by $32 \%$. These changes evidence the intensifying the Krebs cycle functioning that is required for energizing the cellular breathing and increase in the supplies of energy equivalents of ATF, NADN for adaptive and cellular metabolism in hepatocyte.

When exposed to petroleum products during 1 month we observed the statistically significant in- crease in the activity of enzymes included into the antioxidative protection system of body, glucose-6phosphate-dehydrogenase - by $22.07 \%$ and glutathione reductase - by 2.5 times in blood hemolysates. The incresse in the activity of enzyme of glucose-6-phosphate-dehydrogenase is associated with necessity to form the large quantity of HADFN required for the recovery of При oxidized glutathione in the reaction catalyzed by glutathione reductase. Herewith, the changes in the other AOS indicator in the animals of experimental group (activity of Superoxide dismutase and $\Gamma$ Glutathione 
transferase, level of free SH-group in blood hemolysates) are not observed. The content of malonic dialdehyde, bitirosine and tryptophan did not differ from the indicators of control group.

\section{Conclusions:}

1. Based on the results of studies we established that the repeated intragastric introduction of petroleum products in different doses during one month does not cause the manifestation of intense sympthims of intoxication and death of animals that evidences the absence of abity to cumulate at the level of fatal effects. Коэффициент кумуляции составил $>5,1$. Under the degree of intensity of cumulative effect the petroleum products are classified as having the low cumulative activity (fourth group of cumulativity) [4]. The long-term intake of petroleum products had the certain impact on the functions of urinary system which manifested in the kidney RWC increase, oriented differently depending on the dose change in the content of total protein, urea, creatinine and chlorides in urine. We observed the negative impact on liver that is evidenced by the increase of liver RWC and level of total bilirubin in the blood serum. Repeated intake of petroleum products affected the lipidic metabolism - decrease of blood serum triglycerides and cholesterol and morthological composition of blood - increase in the level of hemoglobin, hematocrit, thrombocytes $и$ and average thrombocytes volume. The intake of petroleum products contributed to the development of changes in the system "lipid peroxidation - antioxidative protection system of body" manifested in the accumulation in blood of malonic dialdehyde and free SH-groups in blood hemolysates as well as the increase in the activity of enzymes of superoxide dismutase and glutathione reductase.

2. The petroleum products in the conditions of long-term epicutaneous impact on $2 / 3$ of surface the tails of white rats did not cause the clinical sympthoms of intoxication, development of erythema and edema as well as the death of animals. At the transdermal route of intake we observed the total toxic impct on body which was expressed in the decrease of body weight of experimental animals. We observed the negative impact on the functional condition of urinary (increase in the content of urea in urine and creatinine in serum, decrease of creatinine clearance) and hepatobiliary systems (liver RWC increase). Also we observed the activation of succinate dehydrogenase in liver homogenates that evidences the increase of the energy metabolism processes in the cell mitochondria. At the transdermal intake of petroleum products we observed the activation of antioxidative protection system of body (increase in the activity of glucose-6-phosphate-dehydrogenase and glutathione reductase in blood hemolysates).

\section{References}

1. Kagan Ju.S. Kumuljacija, kriterii i metody ee ocenki, prognoziro-vanie hronicheskoj intoksikacii [Cumulation, criteria and methods of its assessment, forecasting of chronic intoxication]. Principy i metody usta-novlenija predel'no dopustimyh koncentracij vrednyh veshhestv v vozduhe proizvodstvennyh pomeshhenij, Moscow: Medicina, 1970, pp. 49-65.

2. Metody opredelenija toksichnosti i opasnosti himicheskih veshhestv (toksikometrija) [Methods for determining the toxicity and hazard of chemical substances (toxicometry)]. pod red. I.V. Sanockogo, Moscow: Medicina, $1970,343 \mathrm{p}$.

3. Tehnicheskij kodeks ustanovivshejsja praktiki TKP 125-2008 902040) «Nadlezhashhaja laboratornaja praktika» [Technical code of common practice (TKP 125-2008 902040) "Good laboratory practice"]. Minsk: MZ $\mathrm{RB}, 2008,35 \mathrm{p}$.

4. Trebovanija k postanovke jeksperimental'nyh issledovanij dlja per-vichnoj toksikologicheskoj ocenki i gigienicheskoj reglamentacii veshhestv: Instrukcija 1.1.11-12-35-2004 [Requirements to the arrangement of experimental studies for the primary toxicological assessment and hygienic regulation of substances: Instructions 1.1.1112-35-2004]. L.V. Polovinkin, V.V. Shevljakov, E.S. Jur-kevich i dr. Minsk, 2004, 43 p.

5. Acute health effects of the Hebei oil spill on the residents of Taean, Korea. S.R. Lee [et al.]. Jornal of Preventive Medicine and Public Health, 2010, vol. 43 (2), pp. 166-173. Available at: http://jpmph.org/ search.php? where=aview\&id=10.3961/jpmph.2010.43.2.166\&code=0056JPMPH\&vmode=FULL.

6. Acute health effects of the Sea Empress oil spill. R.A. Lyons [et al.]. Jornal of Epidemioljgy and Community Health, 1999, vol. 53 (5), pp. 306-310. Available at: http: //www.ncbi.nlm.nih.gov/pmc/articles/ PMC1756874/pdf/v053p00306.pdf. 